\title{
Jan Kaźmierski*
}

\section{The Conception of Cluster Support Policy in the Realities of the Polish Economy}

\section{Introduction}

Upon Poland's accession to the European Union one could observe growing interest in economic clustering. The formation of a successful cluster is a lengthy process, not a single act or short-term project. Once formally set up, a cluster develops and evolves through different stages and phases. Economic clustering, especially in the era of globalization, is beneficial to the Polish economy as a whole as well as to all businesses involved [2].

The first economic clusters appeared when classical economists noted that businesses are spread unevenly and concentrated in certain geographical areas. Even today, concentration of competing and collaborating businesses is something that differentiate geographical regions [6]. However, it was M. Porter who coined the term cluster in 1990 when he presented his new theory on operations.

As defined by Porter, a cluster is "a group of interrelated enterprises located in a certain geographical area, comprising [of] specialized suppliers and service providers operating in related sectors of economy as well as linked institutions like universities, standardization institutions, and trade associations. In certain areas they compete, while in others cluster participants collaborate closely" [9].

A review of subject-matter literature as well as practical experiences connected with the organisation of clusters in Europe, suggest, that after the year 2000, new cluster structures have been created as part of projects proposed by local authorities or organisations mediating between the sphere of science and entrepreneurs. Also, through consulting firms and, less frequently, as entrepreneurs' own initiative. This particularly applies to companies operating in high technology disciplines which require regular supplies of knowledge from research institutions. In eight countries of the European Union, the CLOE project (Clusters

\footnotetext{
* University of Lodz, Faculty of Management, Department of Logistics
} 
linked over Europe) has been launched. Its main aim is to enable participating nations to share experiences and exchange relevant information in order to facilitate management of clusters.

As cluster awareness rises, they become a predominant element of national and regional plans concerning economic development. There have been launched thousands of cluster initiatives worldwide, which virtually engage all regions and that number is constantly growing. Those initiatives, occurring in varied forms, presently constitute a generally accepted element of economic development. However, systematic knowledge about that initiative, their structure and ways of managing their development - is surprisingly poor among Polish entrepreneurs.

This article is based on the author's own empirical research realised in the years 2007-2011 and source studies for the most part conducted using the desk research method. The examinations concerned mechanisms and barriers in cluster development in regional areas. The implications and conclusions can be employed in various regions of a country.

\section{A nature and models of clusters}

The cluster concept refers to a theory of economic activity localisation. Its essence is based on the usage of spatial concentration of companies which belong to one or more sectors or other entities (e.g. business environment institutions, public administration bodies, scientific and research and development units) to raise their innovativeness and competitiveness [1]. The main feature which distinguishes cluster from other forms of integration is occurrence of intensive interactions based on competition and cooperation at the same time. This cooperation takes place between corporation, administration and research and development sectors as well as between companies themselves.

There are a number of benefits that stem from the existence of clusters, which increase productivity, innovativeness and competitiveness of implicated enterprises. These advantages result from spatial closeness of numerous independent entities, accumulation of specific knowledge, qualifications and specialisations, easiness in acquiring proper employees and business partners (both associate contractors and service providers) and the realisation of joint actions in some areas (e.g. worker training or promotion). This in turn leads to a reduction of transaction cost (speeding up the process of signing contracts, better access to external financing, quicker technology transfer).

Cooperation between entrepreneurs and the scientific and research sphere entails adjusting program offer and research and development work to local company requirements more effectively. Collaboration with administration in turn enables 
the development of the essential infrastructure and more rational development funds allocation through adapting it in certain business aggregations [7].

Cooperation between corporations within a cluster takes place in different areas at the same time increasing their competitiveness against external entities (e.g. collective promotion, marketing or participation in research projects). Simultaneously, an extensive concentration of firms tightens competition, which forces them to act more innovatively and to raise the quality of offered products [8].

One of the principal motivations behind global scale research on clusters is to establish a complex typology of local systems of production. The current attempts to classify this phenomenon have failed to define it accurately. Generally, two groups of clusters, based on different kinds of developmental aspects have been recognised;

1. Techno Clusters which are linked by positive value, high technology-oriented and strongly connected with renowned universities and research institutions, where they often originate from.

2. Traditional Clusters (Historical) based on know-how and knowledge accumulated over many years and even generations. Their technological orientation is limited as is their co-operation with research centres.

In relation to several common characteristics defining the concept of a cluster, in practise they can be identified as the following forms:

- Geographically concentrated economic activity of a group of companies from the same or similar field, which are often connected with scientific institutions, such as academies and research centres.

- Vertically integrated production chains, namely, a selected group of sectors, where the neighbouring stages of the production process comprise the centre of the cluster. This form often incorporates scientific institutes, businessrelated services and intermediate bodies.

- Whole sectors or economic branches that constitute clusters themselves, for instance - chemical or agricultural cluster.

- A specific form of relations between subjects whose cooperation is based on trust and transfer of knowledge. This form may or may not be geographically concentrated.

With regards to the level of integration and innovation of the environment of a given region, several types of network organisations with enterprise participation can be identified. Regional cluster is the basic type; it is characterised by a concentration of independent enterprises, which operate within the same or similar field, and are located in close spatial proximity. The more elaborate kind of network may be referred to as the regional network of innovation. Here, the organisation 
and co-operation between participants are more advanced; mutual relations are based on trust, shared standards and conventions. This also serves the purpose of encouraging and supporting the progress of innovation.

In the second half of the 1990s there appeared a correlated concept which defines the organisation of an enterprise network within a region, called Regional Innovation System [11]. The innovation system is a structure located within a given geographical territory, supported by administrative activities, and containing innovative networks and institutions closely linked by mutual interaction and cooperation, which is to ensure increased competitiveness of the firms located within the system. Such a network comprises of research institutes, higher education schools, technology transfer centres, chambers of commerce, banks, investors, local government and government agencies, sole enterprises and their networks as well as industrial clusters [4]. This means that clusters of firms are supported by a well-developed infrastructure of intermediaries and creators of innovation who are responsible for the diffusion of knowledge and technology. Services offered by those institutions correspond with the particulars of the predominant industry of a region, which also refers to clusters operating there.

Clusters may be formed by small and medium-size companies from manufacturing and services sectors as well as high-tech and traditional technology sectors [3].

Clusters, as shown by examples, may emerge in all branches: traditional, modern, in industry, services and agriculture. They are characterised by various levels of innovation and varying sizes as it is difficult to indicate which dimensions are ideal for a cluster [5].

The above typology of clusters is unquestionably incomplete. The economic environment in which clusters develop significantly affects their characteristics as well as the dynamics of their development [10].

It is essential to note that terminology presented by specialists investigating the phenomenon of clustering does not sufficiently reflect the fact that cluster is essentially a symptom of a developing function of logistics, as demonstrated by, for instance, the character of relations between its participants. According to the author, it is therefore appropriate to employ the term logistic cluster.

\section{The policy of cluster development support - the conception and organisational models}

The policy of regional development based on clusters consists in coordinating actions from different fields of economic, political and scientific life, resulting in a consistent system and a specific communicating vessels mechanism - science supports production technology, education corresponds to actual requirements 
of labour market, support given to local companies' competitiveness helps them attract foreign investments.

Resignation from a traditional, direct, or, to say outright, manual form of control of a local economy in favour of a indirect and stimulating operation by the self-government authorities poses the main difference between the conception defined above and a classic model of regional development.

Clusters become here a tool of support and revitalisation, they are designed to extort natural enterprise. That is one of the most considerable advantages of conducting CBP - benefits are noticeable for a whole region, not only entities engaged.

In order to define "Cluster-based Policy" by referring to its constitutive features, it can be mentioned, that the policy is:

- Based on cooperation and joint actions,

- Market is its catalyst

- It combines various actors in the so-called triple helix model (usually business, science and local administration)

- It is of a strategic nature, thus helps to generate an overall strategy/vision of of a particular region's development

- It creates new values.

Cluster policy can evince itself in varied models. It might be realised on two grades: central (national politics) and council (regional politics). It can emerge from higher up, i.e. be the aftermath of public of self-government authorities actions. Comparatively, this policy can be the result of bottom-up initiatives, e.g. stem from grassroots initiatives of trade environments. In economic realities, however, the mixed model which embraces creating national frames for the realisation of a regional grade policy is concerned to be the most effective one.

In European Union member states the examples of realisation of the CBP conception can be found in each of these models. Most EU countries have implemented cluster support programs on a national or regional grade. However, there is no general model for that policy. To make a choice of a suitable conception and the tools of realisation, the current state of a country or a region and specific administrational and economic requirements must be taken into consideration.

\section{Polish realities - barriers and restrictions in cluster support policy}

Barriers connected with CBP policy implementation and with cluster development, which they entail, are so numerous and diversified that "lumping" them 
together could entangle them and hinder the assessment of a situation. Thus, it is advised to establish specific criteria of division which enables us to create a more orderly analysis.

According to experiences in terms of Polish successfully functioning clusters, an analysis concerning interviews with cluster coordinators and entrepreneurs, as well as getting acquainted with the official documents of institutions which affect cluster structures' functioning, it is possible to single out four main types of development barriers:

- organisational barriers,

- institutional barriers,

- market barriers,

- mental barriers.

The first type refers to a real shape of Polish economy and its individual segments, especially the $\mathrm{R}+\mathrm{D}$ sector and the system of cluster initiatives' financing. Institutional barriers boil down to relations between already working or potential cluster members and self-government or government administration organs, business environment institutions. Market barriers embrace global economy trends, growth of competitiveness, business cycles (the risk of recessions and crisis). Finally, mental barriers, which can be associated with social and cultural factors, ingrained cooperation rules or lack of social confidence in the public sector.

The barriers of cluster development in Poland mentioned above do not exhaust the subject, on the contrary - it is open to question and as the clustering idea popularises, other obstacles and difficulties occur. Undoubtedly, however, some of them are particularly threatening and of enormous negative potential and impact on the shape of clustering in Poland. Thus, they require special attention. In the general opinion of entrepreneurs themselves small financial resources and low budget are the main hindrance getting in the way of creating a professional cooperation network. To be outright - businessmen complain about lack of money. The outcomes of a research concerning that problem are unambiguous - financial barriers are pointed as most significant by $89,7 \%$ of the managers.

That subjective judgement of business representatives cannot be disregarded, as convictions about financial barriers which are not to overcome discourage from making cluster initiatives and facing reality from the very beginning. However, it is not as unfavourable as it is perceived by entrepreneurs. The view of financial stagnation is for the most part a stereotype and a myth.

Thus, it seems that lack of financial resources is not as much a problem as their availability is. Public institutions' aim is to convince business environments that a cluster budget is sufficient to think of realising those initiatives. Change of 
stereotypical belief in general lack of funds is connected with taking another crucial barrier in stride, which is extortionate bureaucracy. Simplifying the procedures and employing transparent and equal assessment criteria will let entrepreneurs trust public institutions to a larger extent and consequently convince them to use offered means more eagerly.

According to many respondents, mental and structural issues are more important that financial ones. Among mental barriers the most serious problem is mistrust ingrained in Polish society. To a great extent it poses the heritage of the Polish People's Republic. "The culture of distrust" which dominates in Poland results also from low political culture and corruption. That atmosphere is not conducive to build cluster structures, which are formed on the basis of mutual confidence. The success of clusters is directly proportional to trust between entities which form economic connections. Otherwise, it is hard to talk about information and experience exchange, knowledge transfer, innovation diffusions and many other actions, realisation of which is the aim of economic networks.

In the Polish economic system the ideology of competition, rivalry or even open hostility is the dominating one. To some extent it stems from fear of bankruptcy - a lot of Polish, especially small and medium, companies are still not deeply rooted and only just build their position, capture the market. In this situation some reluctance to disclose their know-how to other members of market gambling is partially understandable. In Poland, however, rivalry and completion are too often misapprehended. More openness among entrepreneurs is inevitable. Aversion to partnership and inability to cooperate undoubtedly impede the creation and development of cluster structures.

Another barrier, which is miscomprehension of the cluster idea, in practice means that entrepreneurs' expectations differ from real benefits gained by clustering. These assumptions are usually exorbitant or completely inadequate and deficient. It frequently occurs that the sole motivation to form a cluster structure is availability of public resources (usually European funds). Bringing clusters into existence in order to gain a donation warps the whole idea of clustering. Education, which leads to better understanding of its goals among both entrepreneurs and self-government environments is inevitable here.

To conclude, it is necessary to emphasize that cluster development barriers make up a specific communicating vessels system. Lack of trust in a public area handicaps knowledge transfer and innovation diffusion, which in turn determines low innovativeness of Polish economy. The suspension of these conditions in the long perspective can result in restrictions of European Union resources dispensation. That, in the context of the new Community budget, which gives priority to investments in innovations and knowledge management, becomes a more serious threat. 


\section{Conclusions}

In Poland there is an urge to develop the proper cluster support model and cluster initiatives. Poland, though, is delayed in comparison to other European Union countries. It is assumed that this policy should have a bottom-up nature, which favours entrepreneurs' initiatives. Public authorities (especially regional) should instead serve as a "catalyst for development". They ought to create and stimulate cluster development in the area.

Developing an appropriate cluster support model in Poland should not, however, mean copying or imitating foreign concepts uncritically. Specific realities of Polish economy as well as the proven experiences of other countries must be taken into consideration here.

This approach will help to eliminate a number of barriers which were mentioned above. It will also enable clusters to become a virtual "motor for economic development".

\section{References}

[1] Boekholt P., Thuriaux B., Public Policies to Facilitate Clusters: Background, Rationale and Policy Practices in International Perspective, OECD, 2009.

[2] Bojar E., Bis J., Major Threats to Economic Clusters in Poland, in: The emergence and development of clusters in Poland, Bojar E., Olesiński Z. (ed), Difin, Warszawa 2007, p. 40.

[3] Bucka M., Rozwój klastrów a konkurencyjność matych i średnich przedsiębiorstw, in: Konkurencyjność $i$ potencjat rozwoju polskich metropolii - szanse $i$ bariery, Korenik St., Szołek K. (eds), KPZK PAN, Biuletyn 214, Warszawa 2004.

[4] Cookie P., Schienstock G., Structural Competitiveness and Learning Regions, "Enterprise and Innovation Management Studies" 2000, Vol. 1, No. 3, p. 273.

[5] Enright M.J., Ffowcs-Williams I., Local partnership, clusters and SME globalization, Workshop 2. OECD, Conference for Ministers responsible for SMEs and Industry Ministers, Bologna, Italy, 14-15 June 2008, http://www. oecd.org/dataoecd/20/5/2010888.pdf.

[6] Grycuk A., Koncepcja gron w teorii i praktyce, "Organizacja i Kierowanie", 2003, No. 3(113).

[7] Kaźmierski J., Clusters as a symptom of developing functions of logistics in region, "Scientific Journal - Service Management", 2010, Vol. VI.

[8] Kaźmierski J., Generatory innowacji, "Eurologistics”, 2011, No. 3, pp. 18-21. 
[9] Porter M.E., Porter o konkurencji, Polskie Wydawnictwo Ekonomiczne, Warszawa 2001.

[10] Raport o stanie sektora matych $i$ średnich przedsiębiorstw $w$ Polsce $w$ latach 2005-2008, Rybnicka A., Tokaj-Krzewska A. (eds), Polska Agencja Rozwoju Przedsiębiorczości, Warszawa 2009.

[11] Regional cluster in Europe, European Commission, Observatory of European SMEs 2002, No. 3, p. 14. 